\title{
RISK OF OVERWEIGHT AMONG TEENAGERS WHO FOND TO CONSUME FRIED FOOD IN LOH SUMBER, KUTAI KARTANEGARA
}

\author{
Niken Agus Tianingrum ${ }^{1}$, Aliyansyah Mustofa ${ }^{2}$, Ayunda Dianandari ${ }^{2}$, Mira \\ Susanti ${ }^{2}$, Sarmawati \\ ${ }^{1}$ The Lecturer of Bachelor of Public Health Study Program, Universitas Muhammadiyah \\ Kalimantan Timur \\ ${ }^{2}$ Students of Bachelor of Public Health Health Study Program, Universitas Muhammadiyah \\ Kalimantan Timur \\ *E-mail : nikenagust@umkt.ac.id
}

\begin{abstract}
Teenager (12-18 years old) was a period which vulnerable to the nutritional problem. This was due to two reasons because the teenager needs more nutrition for physical growth and for psychological development. It was also susceptible to change in lifestyle and eating patterns. The purpose of this research was to know the risk of overweight among teenagers who fond to consume fried food in Loh Sumber, Kutai Kartanegara. This research was quantitative with a cross-sectional design to 80 respondents. The sampling technique used a rapid survey method and questionnaire as a research instrument. Data were analyzed by the chi-square test. The result of the research showed the overweight teenagers were as many as 26 people $(32,5 \%)$ and the result of statistical analysis showed that fried foods have a significant association (Pvalue $=0,004 ; \mathrm{OR}=12,5 ; \mathrm{CI}=0,233-3,616)$. The teenagers who fond to consume fried food have 12,5 times greater risk of getting overweight compared with those who did not fond consume fried food. Therefore, researchers giving a recommendation to teenagers to improve the eating pattern and increase physical activity.
\end{abstract}

Keywords: Teenager, Overweight, Fried Food, Kutai Kartanegara

\section{INTRODUCTION}

Adolescence is a period that clearly shows the transition from childhood to adulthood. The transition period is marked by changes in biological, cognitive and social emotional. Adolescence is a period where the teenagers are expected to understand the norms that exist in society without have to be dictated, and have learned to think wisely ${ }^{(1)}$. Generally, adolescence begins at the age of 12 or 13 years old and ends at the late teens or early twenty years old ${ }^{(2)}$. In adolescence, the teenagers can also start issuing their own opinion and they are also easily to be influenced by peers, including the eating habit. The changed eating habit in teenager is affected by lots of factor in which among them is the current globalization that is widely spread out. The teenager is one of groups who are vulnerable to over nutrition ${ }^{(3)}$. 
Over nutrition to the teenager is characterized by a relatively excessive increase in weight when compared to the age or height of their teenage age peers ${ }^{(4)}$. If the fat accumulated in body fat tissue is not burned optimally, it will cause the fat deposits and it can eventually lead to overweight. A lot of fat in body fat tissue can cause teenager to experience obstacles in undergoing daily activities. Overweight is a global health problem with a number of prevalence that is always increasing every year, either in the developed and developing countries. The World Health Organization (WHO) stated that overweight in the childhood and adulthood is one of serious problems in public health in the 21 st century ${ }^{(5)}$. Overweight in the childhood and adulthood tends to last as adults and it can increase the risk of non-communicable diseases such as diabetes and cardiovascular-related diseases.

WHO stated that children at the age of 5-19 years old experienced a significant increase in the overweight status from 1975 and 2016. In 1975, overweight was only around 4\% to the children aged 5-9 years old. But in 2016, the number of overweight to the children aged 5-19 years old increased to be $18 \%$. In $2016,18 \%$ of female teenagers and $19 \%$ of male teenagers sustained overweight ${ }^{(5)}$. Based on the data from Global School-Based Student Health Survey (GSHS) in 2015, stated that percentage of teenagers in 12-16 years of age with fat nutrition were as many as 870 people $(8.44 \%)^{(6)}$.

Overweight can affect to the psychological and emotional consequences ${ }^{(7)}$. In teenager, it can be a risk of depression because it becomes such mockery of their peers. It is also because of the different body shapes and difficulty to get a partner due to the body shape that is not ideal.Overweight is caused by two factors. The first is a genetic factor and the second is an environmental factor. In a research conducted by Andini (2016), the genetic factor of mother and father who have over nutrition will affect their offspring to experience over nutrition as well. The environmental factors which caused the overweight occurrence are the consumption of fatty foods (chocolate, fried nuggets, ice cream, burgers, sausages), lack of physical activity and instant lifestyle.

Fried food can cause overweight if it is consumed in excess and too often. This is related to the research conducted by Syafriani (2018), which is stated that frequently eating fried food was 2.5 times to get risk of being overweight than those who did not often consume fried food. Besides, the research conducted by Mellia Silvy, Irdiandy dkk (2016) stated same thing. Teenagers are 5.7 times at the risk of being obese and overweight due to the consumption of fried foods ${ }^{(10)}$. The habit of consuming fried food can increase the body's energy consumption and can result in an increase of overweight rate. The Fried foods contain $4-14 \%$ fat of total weight. So, the greater the fried food, the more fat in it, so the higher the risk of the overweight can occur.

Based on the description above, the researchers are interested in conducting research with the aim of the research is to know the risk of overweight among teenager who fond to consume fried food in Loh Sumber, Kutai Kartanegara. 


\section{MATERIAL AND METHOD}

This research was a quantitative research with cross sectional design. The sample of this research was as many as 80 teenagers aged 12-18 years old. The sampling technique was carried out using the rapid survey method. The data collection was carried out for one week. Started from November 18 and ended on November 24, 2019

\section{Material}

The instrument of research used questionnaire. The dependent variable in this research was the respondent's overweight condition that was obtained by measuring height and weight. The height measurement used $200 \mathrm{~cm}$ microtoise with an accuracy of $0.1 \mathrm{~cm}$ and the weighing of body weight used manual scales. The independent variable in this research was fried food consumption, which was asked with Yes and No Question.

\section{General Procedure}

Respondents were asked to be measured their weight and also questioned whether they consumed fried food or not. The data processing of teenager in finding out whether it is included in the category of overweight risk is by doing Z-Score calculations using the WHO Anthroplus computer application with the Standard of body weight/height index of teenager with BMI using the Anthropometry Standard Table for Nutritional Status Assessment in the Republic of Indonesia's Minister of Health Decree number: 1995/MENKES/SK/XII/2010.The inclusion criteria in this research were teenagers aged 12-18 years old who lived in Loh Sumber and have a Family Card (KK) located in Loh Sumber. The exclusion criteria were teenagers who lived in Loh Sumber but do not have a Family Card (KK) in Loh Sumber.

\section{Statistical Analysis}

The statistical analysis was firstly conducted by using univariate analysis. The univariate analysis was to know the respondent's characteristic and the second analysis was bivariate analysis used Chi-Square test with a confidence level of $95 \%(\alpha=0.05)$. The Chi-Square test was performed to know whether there is aassociation between fried food consumption and overweight and also the risk.

\section{RESULTS AND DISCUSSION}

The response rate of this research was $100 \%$, which is mean that all respondents were agree to participate. The results of this study are as follows:

Tabel 1.The Characteristics of Respondents

\begin{tabular}{llll}
\hline Variable & & $\mathbf{N}$ & $\mathbf{\%}$ \\
\hline Gender & Male & 42 & 52.5 \\
& Female & 38 & 47.5 \\
\hline Age & 12 & 10 & 12.6 \\
& 13 & 13 & 16.3 \\
& 14 & 12 & 15.0 \\
& 15 & 16 & 20.0
\end{tabular}




\begin{tabular}{llll} 
& 16 & 16 & 20.0 \\
& 17 & 11 & 13.8 \\
& 18 & 2 & 2.5 \\
\hline Nutritional & Malnutrition & 12 & 15.0 \\
Status & Normal Nutrition & 42 & 52.2 \\
& Over nutrition (Overweight) & 26 & 32.5 \\
\hline
\end{tabular}

Source: Primary data, 2019

Table 1 showed that majority of respondents were male were as many as 42 people $(52.5 \%)$. A large age group was the age of 15 and 16 years old with the same number that was 16 people (20\%) and a small age group that is at the age of 18 years old amounted to 2 people $(2.5 \%)$. The teenagers with malnutrition status were 12 people $(15 \%)$, the teenagers with normal nutrition were 42 people (52.5\%) and the teenagers with over nutrition (overweight) were 26 people $(32.5 \%)$.

Tabel 2. The Associationbetween the Fond of Fried Consumption and the Overweight Occurrence and It's Risk

\begin{tabular}{|c|c|c|c|c|c|c|c|c|}
\hline \multirow[t]{3}{*}{ Variable } & & \multicolumn{4}{|c|}{$\begin{array}{l}\text { Nutritional } \\
\text { Status }\end{array}$} & \multirow[t]{2}{*}{ P Value } & \multirow[t]{2}{*}{ OR } & \multirow[t]{2}{*}{$95 \% \mathrm{CI}$} \\
\hline & & \multicolumn{2}{|c|}{ Overweight } & \multicolumn{2}{|c|}{ Normal } & & & \\
\hline & & $\mathrm{N}$ & $\%$ & $\mathrm{~N}$ & $\%$ & \multirow[t]{3}{*}{0.004} & \multirow[t]{3}{*}{12,500} & \multirow[t]{3}{*}{$0.233-3.616$} \\
\hline Fried Food & Yes & 25 & 47.1 & 28 & 52.8 & & & \\
\hline & No & 1 & 6,7 & 14 & 93,3 & & & \\
\hline
\end{tabular}

Source : Primary Data 2019

Table 2 revealed that respondents who liked to consume fried food to the teenager with overweight status were as many as 25 people (47.7\%). Meanwhile, the teenagers with the normal nutrition who liked to consume fried food were as many as 28 people $(52.8 \%)$. The result of chisquare test with a $95 \%$ confidence level regarding consumption of fried foods showed that there was an association between the fond of fried food consumption and the overweight consumption to the teenager in Loh Sumber, Kutai Kartanegara ( $\mathrm{p}$-value $=0.004$; or $=12,500 ; \mathrm{CI}=0,233$ $3,616)$.

The result of this research showed that the cconsumption of fried food was 12.5 times more at risk to experience overweight than those who did not consume fried food (or 12,500). This research is in line with the research of Syafriani (2018) stated that consuming foods that are often fried was 2.5 times to get risk of experiencing overweight in adolescence compared to those who did not consume fried foods frequently ${ }^{(9)}$. This is in line with the research conducted bt Mellia Silvy Irdianty, et al (2016) who in their research stated that teenager is susceptible to experience overweight 4 times higher due to the fond of consuming fried foods ${ }^{(10)}$. A similar study was also carried out by Pillar Guallar Castillon, et al (2012). In his research, he mentioned that people who consumed fried foods have a risk of 1.41 times to experience overweight ${ }^{(12)}$. 
The foods that are fried contain $4-14 \%$ fat of its total weight ${ }^{(11)}$, so that the greater the weight of the fried food, the more fat is consumed. During the time of foods being fried, the foods are soaked in whole or soaked in part in oil that is heated to the temperature above $1800 \mathrm{c}$. This process modifies the food in the frying pan. The amount of oil absorbed by food during the frying process depends on what kind of food is fried and what kind of frying condition, but it is estimated that $20 \%$ of the oil is absorbed into the food during the frying process ${ }^{(13)}$. Frying increased the amount of cholesterol in the food ${ }^{(14)}$. Fried foods also showed higher fat and calories. For example, one serving of baked potatoes weighing 100 grams contains 93 calories and 0 grams of fat. Meanwhile for one portion of fried potatoes with the same weight that is 100 grams contain 319 calories and 17 grams of fat ${ }^{(15)}$. If this food was consumed everyday, in short terms, teenagers might experiencing an acne vulgaris ${ }^{(16)}$. This condition is not only become a problem to their look, but also discomfort them. Later, unstable body metabolism will leads to overweight and obesity.

Overweight that occurs in the teenage age can continue in the adulthood and become a factor in the occurrence of health problems such as diabetes mellitus and cardiovascular diseases such as hypertension, stroke and coronary heart disease. Fried food consumption is still considered as a normal thing in society. This is due to the savory taste, its crunchy texture or crisp, easy to produce, easy to be obtained by any kind of age group that became of the reasons why the consumption of fried food is considered as common thing in society.

The repeated use of cooking oil has also an impact on health ${ }^{(11)}$. The repeated use of cooking oil can reduce the quality of the cooking oil itself so that the foods that are fried can also be decreased in their quality and nutritional value ${ }^{(11)}$. The deterioration of the cooking oil occurred due to the use of high temperature for a long time of frying and it triggers an oil oxidation reaction ${ }^{(17)}$. Foods that are fried in oil that is heated continuously with high temperatures will increase the content of trans fatty acids so that the cholesterol content in the body will increase. If the foods that are fried consumed in large quantity every day, it will have an impact on the body's metabolism and it increase the amount of fat in the fat tissue of the body if it is not burned with adequate physical activity.

\section{CONCLUSION}

Based on the characteristics of the research sample, it was found that 25 teenagers $(47.1 \%)$ were detected as having over nutrition risk (overweight.Based on the data analysis and discussion of material regarding the associationbetween the fond of fried food consumption and the overweight occurrence to the teenager in Loh Sumber, it can be concluded that there was a relationship between the two Kartanegara ( $\mathrm{p}$-value $=0.004$; or $=12,500 ; \mathrm{CI}=0,233-3,616$ ). The results obtained from statistical analysis, it was found $\mathrm{OR}=12,500$. The meaning was the fond of the fried food consumption was at risk of overweight as much as 12.5 times than those who did not like the consumption of fried foods. 


\section{REFERENCES}

1. Fatmawaty R. Memahami Psikologi Remaja. J Reforma. 2017;VI(02):55-65.

2. Khamim Z P. Memahami Ciri dan Tugas Perkembangan Masa Remaja. J Apl Ilmu-ilmu Agama. 2017;17(ISSN 1411-8777):25-32.

3. Dinar Agmida. Perbedaan status gizi pada remaja putri berstatus gizi normal dan berstatus gizi lebih berdasarkan aktivitas fisik di SMA Batik Surakarta. Implement Sci [Internet]. 2014;39(1):1-15. Available from: http://dx.doi.org/10.1016/j.biochi.2015.03.025\%0Ahttp://dx.doi.org/10.1038/nature10402 \%0Ahttp://dx.doi.org/10.1038/nature21059\%0Ahttp://journal.stainkudus.ac.id/index.php/e quilibrium/article/view/1268/1127\%0Ahttp://dx.doi.org/10.1038/nrmicro2577\%0Ahttp://

4. Aini SN. Faktor Risiko Yang Berhubungan Dengan Kejadian Gizi Lebih Pada Remaja Di Perkotaan.J Public Health (Bangkok). 2014;3(1):1-10.

5. WHO. Global Health Observatory (GHO) : Overweight and obesity [Internet]. Available from: https://www.who.int/gho/ncd/risk_factors/overweight_adolescents_text/en/

6. PUSLITBANG Upaya Kesehatan Masyarakat. Perilaku Berisiko Kesehatan pada Pelajar SMP dan SMA di Indonesia. Badan Litbangkes Kementrian Kesehat RI [Internet]. 2015;1116. Available

from: http://www.who.int/ncds/surveillance/gshs/GSHS_2015_Indonesia_Report_Bahasa.pdf?ua $=1 \mathrm{PO} / / 1$

7. Yayang KR. LY. Path Analysis on the Psychosocial Impact of Obesity or Overweight in Adolescents in Surakarta, Central Java. J Epidemiol Public Heal. 2018;03(02):105-17.

8. Andini AR, Aditiawati, Septadina IS. Pengaruh Faktor Keturunan dan Gaya Hidup Terhadap Obesitas pada Murid SD Swasta di Kecamatan Ilir Timur 1 Palembang.J Kedokt Dan Kesehat. 2016;3(2):114-9.

9. Syafriani. Hubungan Konsumsi Fast Food dan Aktivitas Fisik Dengan Kejadian Overweight pada siswa di SMAN 2 Bangkinang Kota Tahun 2019.J Kesehat Masy. 2018;2(April):9-18.

10. Irdianty MS, Fakhruddin Nasrul Sani. Aktivitas Fisik dan Konsumsi Camilan pada Remaja Obesitas di Pedesaan dan Perkotaan Kabupaten Bantul. Ber Kedokt Masy. 2016;32(7):917.

11. Ilmi IMB. Kualitas Minyak Goreng dan Produk Gorengan selama Penggorengan di Rumah Tangga Indonesia. J Apl Teknol Pangan. 2015;04(02):61-5.

12. Guallar-Castillón P, Rodríguez-Artalejo F, Fornés NS, Banegas JR, Etxezarreta PA, Ardanaz E, et al. Intake of fried foods is associated with obesity in the cohort of Spanish adults from the European Prospective Investigation into Cancer and Nutrition. Am J Clin Nutr. 2007;86(1):198-205. 
13. Flores M, Meyer L, Orellana S, Saravia C, Galdames C, Perez-camino MC. Quality of Lipid Fractions in Deep-Fried Foods from Street Vendors in Chile. J Food Qual Hindawi. 2018;2018.

14. Sudargo T, Sari FT, Naomi ND, Sudargo T, Med JC, Health P. The Correlation Of Obesity , Smoking, Fried Foods Consumption Pattern and Food Intake With Lipid Profile In Civil Servant in Yogyakarta, Indonesia. Int J Community Med Public Heal. 2017;4(3):690-7.

15. McDonell K. How Bad for You Are Fried Foods [Internet]. 2017. Available from: https://www.heatlhline.com/nutrition/why-fried-foods-are-bad

16. Legiawati L. Perawatan Kulit pada Akne. Medicinal Jurnal Kedokteran Indonesia. 2010; 14(2):17-19.

17. Zahra SL, Dwiloka BL, Mulyani S. Pengaruh Penggunaan Minyak Goreng Berulang terhadap Perubahan Nilai Gizi dan Mutu Hedonik pada Ayam Goreng. Anim Agric J. 2013;2(1):253-60. 